\title{
Long-term performance of white clover cultivars oversown into summer-dry hill country
}

\author{
M.B. DODD, G.W. SHEATH, M.E. WEDDERBURN and I.S. TARBOTTON \\ AgResearch, Ruakura Research Centre, Private Bag 3123, Hamilton \\ E-mail: mike.dodd@agresearch.co.nz
}

\begin{abstract}
The performance of three white clover cultivars (Huia, Tahora and Prop) was monitored in summerdry hill country at the Whatawhata Research Centre for 9 years. The cultivars were oversown into three steep north-aspect paddocks in autumn 1990. White clover abundance was measured every spring using line transects, and stolon fragments were sampled to determine the contribution of the cultivars to overall populations by allozyme electrophoresis on three occasions (1991, 1993, and 1994). White clover abundance declined from $\sim 50 \%$ in the first year to $\sim 4 \%$ in 1999 . There were no significant differences in abundance between the three cultivar treatments after year 2. There were significant differences in the contribution of the cultivars to white clover populations after 5 years as follows: Huia 27\%, Tahora 33\% and Prop 56\%. The implications of these results for introducing new white clover genotypes into summer-dry hill country are discussed.
\end{abstract}

Keywords: 'Grasslands Huia', 'Grasslands Tahora', hill country, long-term, 'Prop', summerdry, white clover

\section{Introduction}

The performance of white clover in hill country pastures has been the subject of much study and debate over the past 20 years. It was recognised at an early stage that large-leaved types bred in lowland environments failed to persist under conditions of low fertility, close continuous grazing by sheep and slope induced drought (Forde \& Suckling 1977; Charlton 1984).

During the 1980s, researchers identified two key characteristics as being important for the persistence of genotypes in the variable environment typical of hill country. Williams et al. (1982) showed improved performance of a small-leaved hill country selection over standard cultivars and attributed this to higher stolon density. Macfarlane \& Sheath (1984) argued that an early and profuse flowering type (for greater reseeding) was better adapted for the long-term survival of populations under summer-dry conditions. These contrasting views were undoubtedly influenced by the climatic conditions (i.e., summer moist vs. summer dry) and grazing management environments (i.e., set stocking vs. rotational grazing) in which the proponents worked.

Other than the two cultivars to come out of these research efforts ('Grasslands Tahora' and 'Prop'), there have been few cultivar releases targeted at hill country, relative to the proliferation of cultivars pertinent to more fertile lowland pastures. This probably reflects two main factors. Firstly, the lack of demand for such genotypes under the prevailing economic environment for hill country farming during the 1980s and 1990s, when there was little investment in improving uncultivatable land via oversowing or fertiliser. Secondly, the inconclusive results of studies measuring changes in white clover content and production as a result of sowing new cultivars into hill country. Some trials demonstrated increases (Williams et al. 1982; Chapman et al. 1993) while many observed no change (Barker et al. 1988; Korte \& Quilter 1990; Macfarlane et al. 1990; Webby et al. 1990; Wedderburn et al. 1996).

However, future interest in white clover improvement is likely to centre on developing desirable nutritional characteristics that have the potential to improve animal performance directly, over and above the benefits of increasing clover production. Examples might be genotypes with greater content of tannins or sulphur-based proteins. Thus the clover plant becomes the carrier of novel traits rather than just a source of protein and energy. In this case, consideration must be given to the contribution of new genotypes to white clover populations where resident populations exist. Three investigations of this have been made in hill country (Chapman et al. 1993; Wedderburn et al. 1996; Hopkins et al. 2000), all of which showed highly variable contributions by introduced material to the white clover populations.

In this paper we report the results of a 9-year field experiment designed to test the hypothesis that genotypes with small leaf size, high stolon density and increased reseeding potential would persist in the longterm, and make a significant contribution to white clover populations in a summer-dry hill country environment where cultivation was not possible. 


\section{Methods}

At the Whatawhata Research Centre, three steep (average slopes $>20^{\circ}$ ) north-facing paddocks of approximately one hectare were divided into three blocks. In December 1989, the paddocks were sprayed with Versatill ${ }^{\mathrm{TM}}(0.7 \mathrm{1} / \mathrm{ha})$ to kill resident clover populations and a basal fertiliser dressing of molybdenum superphosphate $(300 \mathrm{~kg} / \mathrm{ha})$ was applied. The white clover cultivars 'Grasslands Huia', 'Grasslands Tahora' and 'Prop' were randomly allocated to the blocks and oversown into these areas in May 1990 following spraying of the resident pasture with Roundup ${ }^{\circledR}(1.51 / \mathrm{ha})$. The seed mixtures consisted of one of the three white clover cultivars $(3 \mathrm{~kg} / \mathrm{ha}$ uncoated), high endophyte Droughtmaster and Ellett ryegrass $(6 \mathrm{~kg} / \mathrm{ha}$ each) and 'Grasslands Wana' cocksfoot ( $4.5 \mathrm{~kg} / \mathrm{ha})$.

In each block, 10 fixed transect lines of $10 \mathrm{~m}$ length were established. At $25-\mathrm{cm}$ intervals along the transects, pasture species occurrence and slope class were recorded each spring from 1991 to 1999 using the $5 \mathrm{~mm}$ ring technique of Gillingham et al. (1990). Species groups were identified as white clover, other legumes, ryegrass, cocksfoot, other grasses and weeds. Micro-site slopes were identified as flat $\left(<10^{\circ}\right)$, easy $\left(10-25^{\circ}\right)$ and steep $\left(>25^{\circ}\right)$.

The genetic composition of the white clover populations was determined using allozyme electrophoresis (Adam et al. 1993). Soil cores containing rooted nodes of white clover were removed from the paddocks in December 1989, and stolon fragments were sampled from these plants to determine allozyme frequencies for the resident populations. Further stolon fragment samples (100 samples per population, i.e., a total of 900 samples) were taken from each block in November 1991, February 1993 and October 1994.

Following a severe summer drought in 1993/94, seedling and stolon growing point densities were measured in May 1994 using $10 \times 10 \mathrm{~cm}$ quadrats at $50 \mathrm{~cm}$ intervals along the transects. Seedling counts were repeated in May 1995 and stolon counts were repeated in November 1994 and May 1995. Flower counts were also made in January 1994 and February 1995 using $15 \times 15 \mathrm{~cm}$ quadrats at $50 \mathrm{~cm}$ intervals along the transects.

Grazing management of the trial involved rotational grazing with sheep except for the period of flowering and seed set each year, during which time individual blocks were fenced to avoid seed transfer by animals between treatments.

Climate data (monthly actual and normal rainfall) were obtained for the period 1990-2000 from meteorological summaries of data collected at the
Whatawhata station, located within $3 \mathrm{~km}$ of all paddocks (NIWA 1990-2000).

\section{Results}

The first transect abundance measures in 1991 showed that the \% occurrence of white clover at sample points was significantly greater $(\mathrm{P}<0.1)$ in blocks oversown with Tahora (51\%) and Prop (47\%) compared with Huia (28\%). During the subsequent 2 years, the abundance in blocks sown with Huia in spring remained relatively steady, while that of blocks sown with Tahora and Prop declined to reach similar levels to that of Huia (Figure 1). In 1994 following the severe drought (Figure 2), there was a substantial decrease in white clover abundance of all three treatment populations to levels of $15-20 \%$ occurrence (Figure 1). This was followed by an apparent recovery in 1995. For the following 3 years (1996-98), the abundance of all three treatment populations were similar, i.e., in the range of 15-20\% occurrence. In 1999 there was another substantial decrease in abundance of all three treatment populations to $3-4 \%$ occurrence.

Figure 1 Abundance of white clover (\% occurrence at transect sample points) over 9 years following oversowing in May 1990. Bars represent LSD (10\%).

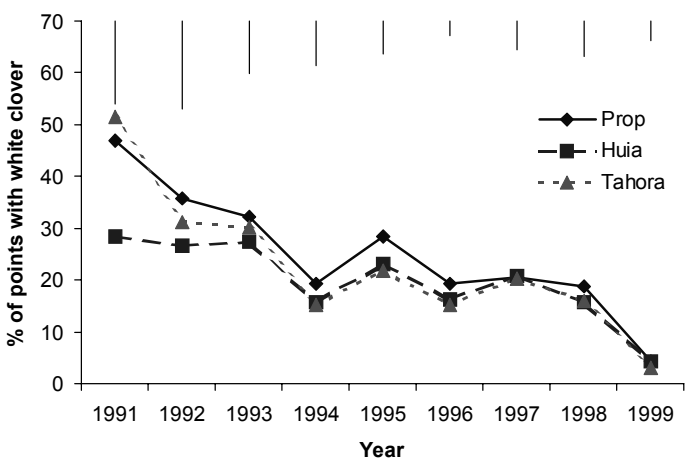

Within the micro-site slope categories, on only one occasion was there a significant difference between treatment populations. In 1996, the abundance of white clover on flat sites was greater $(\mathrm{P}<0.05)$ in the blocks oversown with Prop (25\%) than those of Huia (15\%) and Tahora (15\%).

Measurements of seedling numbers and stolon densities on steep areas in May 1994 and May 1995 showed no significant differences between treatment populations (Table 1). However, in November 1994, stolon densities of blocks sown with Prop were significantly higher than those sown with Huia and Tahora $(\mathrm{P}<0.05)$. Measurements of flower numbers in 
Figure 2 Percent of normal monthly rainfall at Whatawhata for 1990-2000, including the cumulative difference from normal rainfall (mm) for the December-May period each year (inside arrows). The main white clover measurement events are also shown.

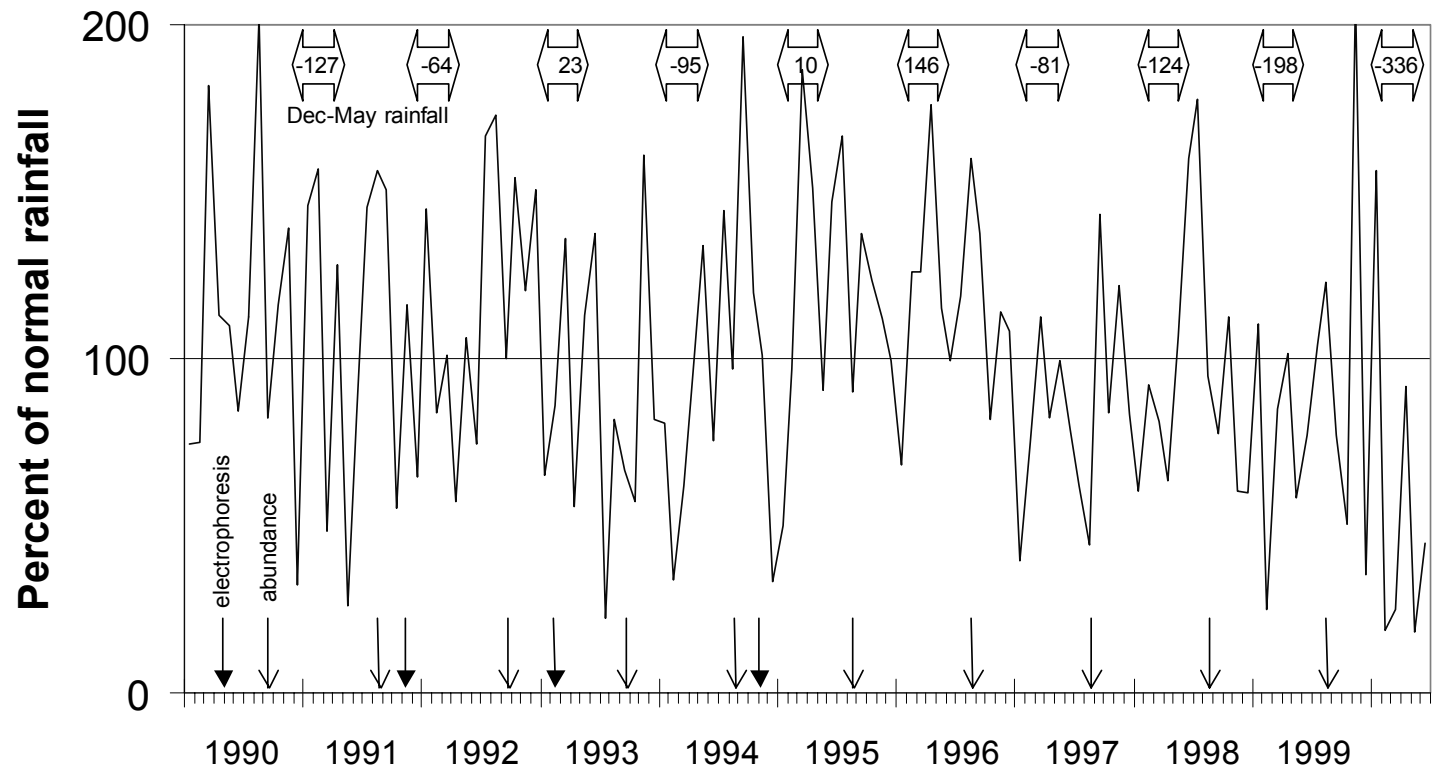

Table 1 Mean seedling and stolon growing tip counts (number/ $\mathrm{m}^{2}$ ) for three white clover populations.

\begin{tabular}{llccc}
\hline & Treatment & May & November & May \\
& population & 1994 & 1994 & 1995 \\
\hline Seedling count & Huia & 37 & - & 5 \\
& Tahora & 51 & - & 2 \\
& Prop & 69 & - & 3 \\
& LSD (10\%) & 44 & - & 6 \\
Stolon points & Huia & 71 & 163 & 347 \\
& Tahora & 61 & 186 & 414 \\
& Prop & 60 & 225 & 465 \\
& LSD (10\%) & 32 & 30 & 121 \\
\hline
\end{tabular}

Table 2 Mean flower counts (number $/ \mathrm{m}^{2}$ ) for three white clover populations.

\begin{tabular}{lcc}
\hline Treatment population & January 1994 & February 1995 \\
\hline Huia & 72 & 49 \\
Tahora & 98 & 37 \\
Prop & 125 & 68 \\
LSD (10\%) & 46 & 32 \\
\hline
\end{tabular}

Table 3 Mean percentage contributions to total white clover population (based on allozyme electrophoresis) of three oversown cultivars.

\begin{tabular}{lccc}
\hline Cultivar & 1991 & 1993 & 1994 \\
\hline Grasslands Huia & 43 & 43 & 27 \\
Grasslands Tahora & 64 & 52 & 33 \\
Prop & 82 & 43 & 56 \\
LSD (10\%) & 45 & 44 & 22 \\
\hline
\end{tabular}

January 1994 and February 1995 showed no significant differences between treatment populations (Table 2).

In November 1991, the proportions of oversown genotypes (as assessed by allozyme electrophoresis) within the white clover populations varied widely, but with no significant differences between cultivars (Table 3). By 1993, the contributing proportions were similar for the three cultivars (40-50\%). In 1994, Prop made a significantly greater contribution $(56 \%, \mathrm{P}<0.1)$ to recovering populations than Tahora and Huia (33\% and $27 \%$ respectively).

\section{Discussion}

White clover abundance declined significantly during the 4-year period following oversowing onto steep summer-dry hill country. Initial levels of up to $50 \%$ occurrence, for the populations based on the two cultivars developed for hill country environments, diminished to $15-20 \%$ occurrence. In 1995 there was a brief reversal of this trend, where abundance increased by $5-8$ percentage points on the previous spring. This temporary recovery coincided with a relatively high rainfall period (1995-96) following a particularly severe drought (1993-94), depicted in Figure 2. The patterns of flower, seedling and stolon counts in the summer/ autumn of 1994 and 1995 (Tables 1 \& 2) indicate a similar response amongst all treatments to these climatic conditions, whereby flower and seedling numbers were higher in 1994 (dry) than 1995 (wet) and stolon points 
were higher in 1995 (wet) than 1994 (dry). During 1996-98, it appeared that the populations had stabilised at the $15-20 \%$ abundance level. This level was comparable to equivalent data collected from local resident white clover populations on similar slopes, which averaged $\sim 16 \%$ occurrence between 1984-97 on the long-term fertiliser trial at Whatawhata (Gillingham et al. 1990). The similarities in total white clover abundance among populations of differing genetic makeup suggests that there is an environmentally determined limit of white clover content that cannot be improved on by new material. It is worth noting that it took 4 years for the populations to reach this level, raising cautions about the interpretation of the results of commonly cited 3-year evaluation trials.

A series of worsening dry summer-autumn periods from 1997 onwards (Figure 2) appears to have ultimately led to a substantial drop in the abundance of white clover between 1998-1999. Observations since the last abundance measure (1999) indicate that no subsequent recovery has occurred. The impact of the clover root weevil (Sitona lepidus) may have been an exacerbating factor, its arrival at Whatawhata being noted in 1996, though minimal feeding damage was observed in these paddocks. This population collapse, for whatever reason, should provide a rigorous test of the adaptive characteristics of the cultivars over the resident genotypes.

As has been noted in other experiments, the gradual recovery and eventual domination of resident genotypes over introduced material was largely confirmed in this trial, at least in respect of the cultivars Huia and Tahora. Under similar conditions (low fertility hill slopes of $\sim 20^{\circ}$ under rotational sheep-grazing), Hopkins et al. (2000) observed a $22 \%$ contribution of Huia to white clover populations 11 years after sowing. In addition, the similarity in total white clover abundance of the oversown pastures relative to local resident pastures, shows that the value of oversowing these genotypes to increase clover content in this environment is minimal. After 5 years, these genotypes contributed only $\sim 30 \%$ to white clover populations in the field, implying that the introduction of any novel traits would have minimal effect on animal performance unless they provided large proportional benefits. However, the contribution of Prop to field populations after 5 years was over $50 \%$. This provides some encouragement that it will be possible to establish a well-adapted cultivar as a carrier for novel traits that might be incorporated via breeding or genetic modification. However, it is important to note that in this case, the well-adapted cultivar has a strong emphasis on propagation by reseeding, in a species with a high rate of outcrossing. Therefore the maintenance or spread of any such new trait requires that it be a dominant trait. What is clear is that any assessment of new white clover cultivars sown into resident populations must include a robust measurement of the contribution of those genotypes to clover populations in the field.

\section{Conclusions}

On steep hill country paddocks in summer-dry environments, total white clover content was determined more by environmental influences than genetic differences. Summer drought substantially decreased white clover abundance irrespective of the genetic composition of the populations. Recovery of overall populations after drought also did not appear to be influenced by genotype, although Prop contributed more to the resultant populations than did Tahora or Huia. Both seedling recruitment and stolon perenniation were important in this respect. Evaluations of the introduction of new white clover cultivars to pastures where resident populations exist should be accompanied by analysis of the contribution of those genotypes to overall populations.

\section{ACKNOWLEDGEMENTS}

This study was funded by Agriseeds NZ Ltd. Various staff of MAFTech and subsequently AgResearch, assisted with field work.

\section{REFERENCES}

Adam, K.D.; Wedderburn, M.E.; Greaves, L.A.; Faville, M. 1993. Use of allozyme markers to follow the establishment of white clover sown into hill country. Proceedings of the XVII International Grassland Congress: 1046-1048.

Barker, D.J.; Chapman, D.F.; Anderson, C.B.; Dymock, N. 1988. Oversowing 'Grasslands Wana' cocksfoot, 'Grasslands Maru' phalaris and 'Grasslands Tahora' white clover in hill country at varying rates of paraquat and glyphosate. New Zealand Journal of Agricultural Research 31: 378-382.

Chapman, D.F.; Mackay, A.D.; Devantier, B.P.; Dymock, N.; Anderson, C.B. 1993. Effects of cultivar introduction and fertiliser on characteristics of white clover (Trifolium repens L.) plants and populations in a hill country pasture. New Zealand Journal of Agricultural Research 36: 87-98.

Charlton, J.F.L. 1984. Persistence of Grasslands Huia white clover (Trifolium repens L.) in hill country pastures. Proceedings of the New Zealand Grassland Association 45: 131-139.

Forde, M.B.; Suckling, F.E.T. 1977. Sampling white clover (Trifolium repens L.) from New Zealand 
hill-country pastures. Proceedings of the $3^{\text {rd }}$ International SABRAO Congress 2:14(6): 15-18.

Gillingham, A.G.; Richardson, S.; Power, I.L.; Riley, J. 1990. Long term effects of withholding superphosphate application on North Island Hill country: Whatawhata Research Centre. Proceedings of the New Zealand Grassland Association 51: 11-16.

Hopkins, A.; Lambert, M.G.; Barker, D.J.; Costall, D.A.; Sanders, P.M.; Scott, A.G.; Williams, W.M. 2000. Determination of management and topographic influences on the balance between resident and 'Grasslands Huia' white clover (Trifolium repens) in an upland pasture using isozyme analysis. Journal of Agricultural Science, Cambridge 134(2): 137145.

Korte, C.J.; Quilter, S.J. 1990. Effects of summer grazing and fertiliser on the clover content of hill country swards in the Gisborne region. Proceedings of the New Zealand Grassland Association 51: 113118.

Macfarlane, M.J.; Sheath; G.W. 1984. Clover - what types for dry hill country? Proceedings of the New Zealand Grassland Association 45: 140-150.
Macfarlane, M.J.; McGowan, A.W.; Sheath, G.W.; Korte, C.J. 1990. An on-farm evaluation of white and subterranean clovers in North Island hill country. Proceedings of the New Zealand Grassland Association 51: 157-162.

National Institute of Water and Atmospheric Research Ltd (NIWA). New Zealand Climate Digest. January 1990-December 2000.

Webby, R.W.; Sheath, G.W.; Boom, C.J. 1990. Performance of new pasture cultivars in a hill country finishing system. Proceedings of the New Zealand Grassland Association 51: 151-156.

Wedderburn, M.E.; Adam, K.D.; Greaves, L.A.; Carter, J.L. 1996. Effect of oversown ryegrass (Lolium perenne) and white clover (Trifolium repens) on the genetic structure of New Zealand hill pastures. New Zealand Journal of Agricultural Research 39: 41-52.

Williams, W.M.; Lambert, M.G.; Caradus, J.R. 1982. Performance of a hill country white clover selection. Proceedings of the New Zealand Grassland Association 43: 188-195. 